\title{
32. GEOCHEMICAL SIGNIFICANCE OF GAS AND GASOLINE-RANGE HYDROCARBONS AND OTHER ORGANIC MATTER IN A MIOCENE SAMPLE FROM SITE 134 - BALEARIC ABYSSAL PLAIN
}

\author{
Richard D. McIver, Esso Production Research Company
}

\begin{abstract}
Gasoline-range hydrocarbons as well as gaseous ones are apparently seeping upward into immature, late Miocene, nonreservoir sediments in the area of Site 134 of the DSDP Leg 13 Mediterranean cruise. These conclusions are drawn from the results of geochemical analyses of a specially collected core sample. This sediment contains significant quantities of light hydrocarbons, but the rest of the organic matter appears to be so immature that it could not produce these light hydrocarbons, particularly the gasoline-range ones. Hence, the occurrence must be considered a minor but significant seepage from below. While not as spectacular as the show at Challenger Knoll (Gealy and Davies, 1969; Davis and Bray, 1969), this "show" is another indication that petroleum has already begun to form and migrate in some shallowly-buried deep-sea sediments.
\end{abstract}

\section{INTRODUCTION}

Section 1 of Core 10, recovered from a sediment depth of about 362 meters under 2870 meters of water at Site 134 , was reported to have smelled strongly of "methane." This prompted shipboard scientists to seal about 600 grams in a gallon jar for subsequent analyses. This container was returned to Woods Hole Oceanographic Institution from whence it was hand-carried to Houston, Texas.

Site 134 was one of three $(124,133$ and 134) cored in the Balearic Basin to answer a long-standing dispute on the age of evaporitic rocks which were interpreted to underlie the basin (W. B. F. Ryan et al., 1970). This interpretation was based on both their apparent diapiric (piercement) character and the nature of the reflections.

According to the shipboard record of lithostratigraphy, an upper Miocene evaporitic suite was encountered between 324.3 and 364 meters, where Cores 8 and 9 contain massive, laminated anhydrite interbedded with transparent halite. Core 10 recovered more massive laminated anhydrite on top of a black, plastic anhydrite-pyrite sediment (70\% and $30 \%$ respectively) which emitted a strong "methane" odor. Beneath this was massive halite with thin anhydrite beds.

The shipboard core summary describes the sediments of Core 10, Section 1 as: dolomitic ooze, layered dark gray, N4, and black N0. Methane odor. Composition: dolomite, quartz, clays, anhydrite and halite.

\section{ANALYTICAL METHODS}

Generally, the methods employed have been reported in the literature. While the original reference is noted in the appropriate section, details of most of them are reviewed in one of the contributions (Koons and Monaghan, 1969) in Initial Reports of the Deep Sea Drilling Project, Volume I.
Where our methods were somewhat different, these changes will be described in the text.

In order to avoid possible loss of anticipated small quantities of gas from the sample container (and possible contamination), a rubber hypodermic septum was glued to the metal jar top. The needle of a hypodermic syringe was plunged directly through the septum and lid into the jar's rather large gas space. A $1 \mathrm{cc}$ gas sample was withdrawn and was inserted into the inlet port of a Perkin Elmer 154B gas chromatograph with flame ionization detector and a $2 \mathrm{~m}$ $1 / 4$ o.d. column packed with di-2-ethyl hexyl sebacate on 60-80 mesh chromosorb W. Helium flow rate was 38 $\mathrm{ml} /$ minute; hydrogen flow rate was $20 \mathrm{ml} /$ minute; air, 350 $\mathrm{ml} /$ minute.

Next, the jar was opened and approximately $100 \mathrm{ml}$ of the sediment was removed, placed in a Waring blender, and agitated for further removal of the gaseous hydrocarbons. A gas sample was withdrawn from the air space of the blender and was inserted into the gas chromatograph for analyses as above. From the volumes of gas analyzed, the gas space in the jar, and the sediment itself, the hydrocarbon contents of the sediment were calculated on a per volume basis. Results are given in Table 1.

A $1 \mathrm{ml}$ sample of the original sediment sample was taken for determination of gasoline-range hydrocarbons. The procedure was that reported by Dunton and Hunt (1962). These results are also given in Table 1.

Another small sediment sample was removed for determination of stable isotope measurement of $\mathrm{C}^{12}$ and C13 on the total organic matter by methods described by Rogers and Koons (1969).

Still another aliquot of the original sediment sample was taken for enrichment of particulate organic matter for study under the microscope as described by Staplin (1969). 
Finally, the remaining sediment was subjected to our procedures for organic carbon and extractable organic components by the methods described by Gehman (1962). Saturate and aromatic hydrocarbon fractions from column chromatography were further analyzed by mass spectrometry (as, in Lumpkin, 1956 and 1958) and the saturates were analyzed by the gas chromatograph, as per Koons and Monaghan (1969) to determine their carbon preference index (CPI).

All the analytical results are listed in Table 1.

\section{GASEOUS HYDROCARBONS}

The sample (gas space and sediment) contained gaseous hydrocarbons corresponding to $13,384 \mathrm{ppm}$ by volume of the sediment. Ninety-three per cent of this was in the gas-space of the jar, and had apparently been released because of the reduction in pressure and the prolonged storage. The total gas both in the gas space and sediment is probably only a small fraction of that released by the core. The fact that the sample contains gas is not surprising. Shipboard scientists report gas in many DSDP cores. But this sample contained over 9 per cent gases heavier than methane. The ethane-plus content is lower than that in the gas reservoired with the heavy oil at Challenger Knoll in the Gulf of Mexico (Erdman, 1969), but the fact that it has any implies the gas is not just normal, bacterially-produced methane gas produced by young sediments, but a gas from thermal alteration of sediments that may be part of the oil-forming process (Philippi, 1965 and 1968).

\section{GASOLINE-RANGE HYDROCARBONS}

The sample also contains $909 \mathrm{ppb}$ (parts per billion) by volume of $\mathrm{C}_{4}-\mathrm{C}_{7}$ gasoline-range hydrocarbons of which methylcyclopentane is most abundant (293 ppb). Methylcyclopentane, isopentane (102 ppb), normal pentane (101 $\mathrm{ppb}$ ), and normal hexane (103 ppb) make up about two-thirds of the hydrocarbons in this range. The total quantity of gasoline is well above background for the method, $40 \mathrm{ppb}$, and individual hydrocarbons run well above their detection limits, about $5 \mathrm{ppb}$. The quantity is intermediate between those described for shallow, Recent (unaltered) sediments and presumed altered ones from deeper oil-producing sections (Dunton and Hunt, 1962). Therefore, we feel the $\mathrm{C}_{2}-\mathrm{C}_{7}$ hydrocarbons found in this sample indicate that the thermal alteration of organic matter is proceeding in some of the sediments in the area of Site 134 .

However, the gasoline is unusual when compared with either typical crudes or young, immature ones (Davis and Bray, 1969; Mommessin et al., 1969; Erdman et al., 1969; and Koons and Monaghan, 1969). In particular, the relatively few components, the equal quantities of iso-and normal pentane, the unusual abundance of methylcyclopentane, and the paucity of aromatics and dimethylpentanes make this sample atypical. This may reflect a source which is very limited in the number of precursors actually available to form this unusual distribution, but this seems unlikely. Whatever the cause, gasoline-hydrocarbons have begun to form in these or contiguous sediments.
TABLE 1

Organic Geochemical Analyses of Upper Miocene Sample, Leg 13

Site 134, Core Barrel 10, Section 1

Sediment Depth: $361.5-362 \mathrm{~m}$

Latitude: $39^{\circ} 11.84^{\prime} \mathrm{N}$

Water Depth: $2870 \mathrm{~m}$ Longitude: $7^{\circ} 17.96^{\prime} \mathrm{E}$

Western Mediterranean Sea

Total Organic Carbon

$0.71 \%$

$\delta \mathrm{C}^{13} / \mathrm{C}^{12}$ of total organic matter $20.6 \%$

Gaseous Hydrocarbons

Methane

Ethane

Propane

Isobutane

n-Butane

TOTAL

Gases heavier than Methane -

$11,223 \mathrm{ppm}$ (by volume) 1,006

79

24

$\frac{53}{12,385}$

$9.5 \%$

$\mathrm{C}_{4}-\mathrm{C}_{7}$, Gasoline-Range Hydrocarbons

Isobutane

n-Butane

Isopentane

n Pentane

Cyclopentane

2-Methylpentane

3-Methylpentane

n-Hexane

Methylcylopentane

Cyclohexane

1,1-Dimethylcyclopentane

1c3-Dimethylcyclopentane

1t2-Dimethylcyclopentane

2,3-Dimethylpentane

3-Methyl Hexane

n Heptane

Methylcyclohexane

TOTAL

$35.2 \mathrm{ppb}$ (by volume)

67.0

101.6

100.5

43.8

46.8

15.1

103.4

293.0

11.0

6.6

30.2

15.4

7.1

6.3

22.0

$\frac{3.7}{908.7}$

Extractable Bitumens

- Total Soluble Organic Matter

Asphaltenes

Pentane Soluble Nitrogen Sulfur Oxygen

$\mathrm{C}_{15}+$ Hydrocarbons Saturates $27 \%$

Aromatics

73

Saturate/Aromatic Ratio $\quad 0.375$

1,978 ppm (by weight)

1,833

$92.6 \%$

119

6.0

26

1.4

- Mass Spectrometric Characterization of Saturated Hydrocarbons

$\begin{array}{lllr}\text { Paraffins } & 24.6 \% & \text { 4 Ring Naphthenes } & 8.3 \% \\ \text { 1 Ring Naphthenes } & 17.9 & \text { 5 Ring Naphthenes } & 13.9 \\ \text { 2 Ring Naphthenes } & 15.0 & \text { 6 Ring Naphthenes } & 8.1\end{array}$

3 Ring Naphthenes 12.1

- Mass Spectrometric Characterization of Aromatic Hydrocarbons

$\begin{array}{lrlr}\text { Benzenes } & 21.2 & \text { Dihydrophenanthrenes } & 6.5 \\ \text { Indanes } & 11.0 & \text { Phenanthrenes } & 2.0 \\ \text { Indenes } & 10.7 & \text { Pyrenes } & 11.0 \\ \begin{array}{l}\text { Naphthalenes } \\ \text { Tetrahydro- }\end{array} & 1.2 & \text { Chrysenes } & 14.4 \\ \quad \text { phenanthrenes } & 2.0 & \text { Dibenzotheophenes } & 2.3\end{array}$




\section{INSOLUBLE ORGANIC MATTER}

The organic carbon content, 0.71 per cent, is more than sufficient to account for the light hydrocarbons. This value is in the high range of DSDP samples on a worldwide basis (McIver, 1970 and 1971; Koons, 1971) except for the Cariaco trench (DSDP staff, personal communication). However, the mere contents of organic carbon and light hydrocarbons does not mean that these hydrocarbons are indigenous to the sediments at 362 meters in this core hole. The host sediments may not be source of these lighter constituents and, as the discussion below will show, they probably are not.

Examination of the enriched, insoluble organic matter under the microscope reveals primarily a yellow, coaly material, and secondarily an amorphous material. In appearance, they are equivalent to the unaltered organic matter in the Staplin (1969) scheme. Hence, any gas associated with this sediment may be expected to be methane gas. The 9 per cent ethane-plus in the associated gas is inconsistent with a lack of alteration. Therefore, it is reasonable to assume that the gas is not indigenous, but has migrated into this zone.

The insoluble organic matter contains abundant angiosperms and fungal spores, and frequent gymnosperms, which suggests that much of the organic matter is land-derived. There are a few planktonic forms (hystrichospherids and dinoflagellates), but they are much less abundant than the pollen or fungal spores. The terrestrial source is supported by the results of analysis of the saturated heavy $\left(\mathrm{C}_{15+}\right)$ hydrocarbons described in the next section.

In contrast, the carbon isotope ratio of the organic matter insoluble in hydrochloric acid (used to dissolve carbonates that would interfere with the analysis) is -20.6 vs. the Peedee Belemnite standard. This shows that, in spite of the other parameters, a significant portion of the organic matter in the sediment is of marine origin (Silverman and Epstein, 1958). It must be a mixture of organic material from terrestrial and marine sources.

\section{EXTRACTABLE ORGANIC MATTER (BITUMENS)}

Upon extraction with 70:15:15 benzene-acetonemethanol mixture, the sample yielded $1978 \mathrm{ppm}$ by weight of extractable organic matter. This was far above the quantity of extractable organic matter in Leg 4, 5 and 6 cores, for example, but was an order of magnitude below the quantity of extractable bitumen in the Challenger Knoll core (saturation). Upon dilution with pentane, $1833 \mathrm{ppm}$ (93\%) of the extract precipitated. Thus, the extract consists primarily of asphaltenes. Results of column chromatography revealed that the remaining pentanesoluble bitumen was comprised of $26 \mathrm{ppm}$ hydrocarbons and 119 ppm NSO's (nitrogen, sulfur, and oxygen compounds). The hydrocarbon is made up of $8 \mathrm{ppm}$ of saturates and $18 \mathrm{ppm}$ of aromatics.

This extract, then, looks nothing like an accumulated oil such as the one found at Challenger Knoll (Davis and Bray, 1969). The asphaltene to heterocompound to aromatic hydrocarbon to saturated hydrocarbon percentages of this extract (92.6:6.0:1.0:0.4) are more heavily weighted toward the larger, more complex molecules than they are in the Challenger Knoll oils (for example, 14:19:37:30). Even if the large preponderance of asphaltenes were ignored, the Balearic sample is still heavily weighted toward the heteroor NSO compounds (heterocompound: aromatic hydrocarbon: saturated hydrocarbon proportions of $82: 12: 6$, vs. 20:27:53 for the Challenger Knoll saturation.

The extremely low hydrocarbon to bitumen ratio suggests that virtually no thermal alteration has taken place in the host sediment. The very small amount of hydrocarbons further suggests this rock cannot in its present condition be considered a source of petroleum according to criteria set out by Philippi (1956) and Bray and Evans (1969). Perhaps all that would be required to convert it to a potential active source would be some thermal alteration which is the likely fate of such organic matter (Philippi, 1965 and 1968).

The apparently contradictory suggestions of virtually no thermal alteration from the heavy hydrocarbon and bitumen contents and of significant alteration from the amounts of $\mathrm{C}_{2}-\mathrm{C}_{7}$ hydrocarbon can be resolved by calling upon deeper thermally-altered sediments to generate the light hydrocarbons which then have migrated or seeped upward into an immature (or virtually unaltered) sediment. The light hydrocarbons have been halted in their migration upward by the massive anhydrite, a potential hydrocarbon seal.

The composition of the saturated-hydrocarbon fraction gives further support to the suggestion that part of the organic matter and heavy hydrocarbon in the Miocene sediment are terrestrial in origin. The gas chromatograph of the saturate fraction, Figure 1, shows marked preference for the odd-carbon normal paraffins. The calculated carbon-preference index (as originally defined by Bray and Evans, 1961) is 1.7 (Over the entire range of heavy hydrocarbons the CPI is 2.2.). As Koons et al (1965) and Bray and Evans (1961) have discussed, CPI's in this range indicate a hydrocarbon at least partly derived from terrestrial organic matter (as well as hydrocarbon not severely altered, thermally). This moderate preference for odd-number carbon-chain length has not been found in reservoired petroleums. Moreover, it is not like that in the saturation at Challenger Knoll.

Mass spectrometry of the saturate fraction shows that the hydrocarbons tend more toward the larger ring sizes, especially the 4-, 5-, and 6-ring naphthenes, than the extracts from the Challenger Knoll (Koons and Monaghan, 1969 and Mommessin et al., 1969). The aromatic fraction is also distributionally different in the two contrasting situations, but no reason can be given for this difference except that the original source materials were probably quite different.

\section{CONCLUSIONS}

Although two previous DSDP coreholes have penetrated sections that apparently contain migrated hydrocarbons (Gealy and Davis, 1969; McIver, 1971) this newly recognized minor accumulation or, more properly, enrichment, in an upper Miocene sediment of Site 134 is unusual in that only gaseous and gasoline hydrocarbons appear to have migrated. These lighter compounds now reside in 


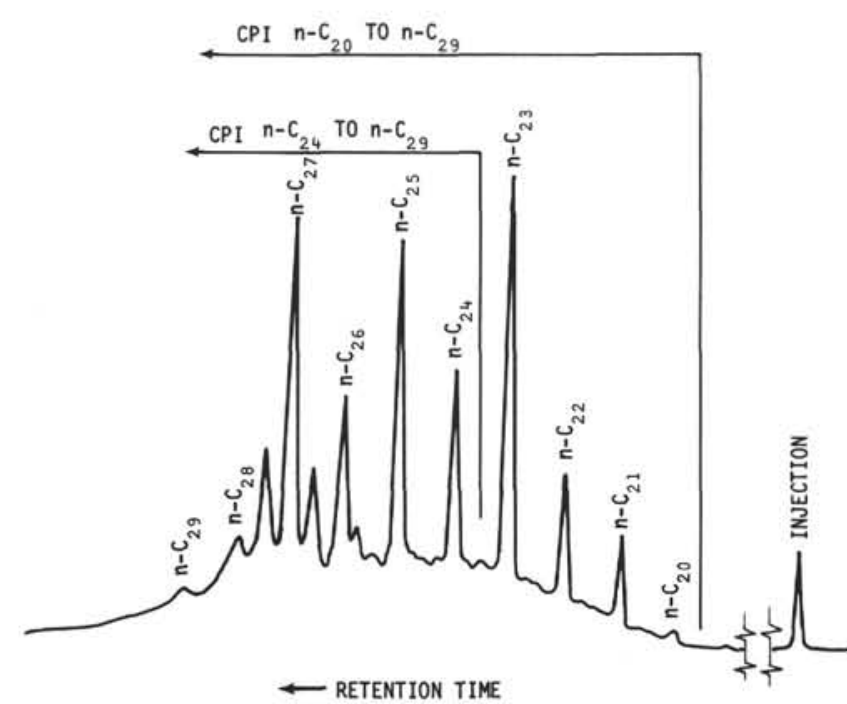

Figure 1. Gas chromatogram saturated hydrocarbons from extract of Leg 13, Site 134 sample.

thermally unaltered marine sediments, the bulk of whose organic matter (insoluble organic matter and bitumens) came both from the overlying ocean and from one or more of the continental masses that surrounded it during sedimentation.

The migrating material is very unusual in its relative simplicity (in terms of numbers of compounds) and in the relative abundance of individual gasoline-range hydrocarbons. While this unique character cannot be explained, the presence of the light hydrocarbons in these quantities does indicate that at least early stages of thermal alteration of organic matter are going on in sediments contiguous to sample Site 134, and some hydrocarbons have apparently begun to move, though in quantities that are still far from economically significant.

\section{ACKNOWLEDGMENTS}

The author wishes to express appreciation to Jim Morgan, Louis Franklin, Harvey Fry, Tom Connary, Paul McAnich and Joe Walker, Jr., who assisted with the analyses; to C. B. Koons who made helpful suggestions during the writing of this report; and to the National Science Foundation and the Deep Sea Drilling Project who made this interesting sample available for study.

\section{REFERENCES}

Bray, E. E. and Evans, E. D., 1961. Distribution of n-paraffins as a clue to recognition of source rocks. Geochim. Cosmochim, Acta. 22, 2. 1969. Organic extracts from JOIDES cores off northeastern Florida. Geol. Surv. Profess. Paper 581-C U.S. Gov't Printing Office, Washington, D.C., C1 .

Davis, J. B. and Bray, E. E., 1969. Analysis of oil and cap rock from Challenger (Sigsbee) Knoll in Ewing, M. W., Worzel, J. L., et al., Initial Reports of the Deep Sea Drilling Project, Vol. I. Washington (U. S. Gov't Printing Office), 415 .

Dunton, M. L. and Hunt, J. M., 1962. Distribution of low molecular weight hydrocarbons in Recent and ancient sediments. Bull. Am. Assoc. Petrol. Geologists, 46, 2246.
Erdman, J. G., Borst, R. L., Hines, W. J. and Scalan, R. S., 1969. Composition of gas samples 1 (Core 5) by components, in Davis, J. B., and Bray, E. E. (1969) Above, Section 2.6, 461 .

Gealy, E. L. and Davis, T. A. The deep sea drilling project, Geotimes 14, No. 2, 10.

Gehman, H. M., Jr., 1961. Organic matter in limestones. Geochim. Cosmochim. Acta. 26, 885.

Koons, C. B., 1965, Jamieson, G. W. and Ciereszko, L. S. Normal alkane distributions in marine organisms; possible significance to petroleum origin. Bull. Am. Assoc. Petrol. Geologists. 49, 301.

1971. JOIDES cores, Geochemical analysis of four Gulf of Mexico and western Atlantic sediment samples, Geochim. Cosmochim. Acta. 34, 1353.

Koons, C. B. and Monaghan, P. H., 1969. Data and discussion of analyses by Esso Production Research Company, including $\mathrm{C}^{12} / \mathrm{C}^{13}$ ratios, in Davis, J. B., and Bray, E. E. (1969) Above, Section 2-8, 478.

Lumpkin, H. E., 1956. Determination of saturated hydrocarbons in heavy petroleum fractions by mass spectrometry. Anl. Chem. 28, 1946.

1958. Low voltage techniques in high molecular weight spectroscopy. Anl. Chem. 30, 321.

McIver, R. D., 1971. JOIDES cores, Evidence of migration of hydrocarbons in Pleistocene sediments of the Shatsky Plateau; western Pacific Ocean, in Fisher, A. G., et al., 1971. Initial Reports of the Deep Sea Drilling Project, Volume VI. Washington (U.S. Gov't Printing Office). 1327.

1971. Organic geochemical analyses of frozen samples from DSDP Leg 13 cores, in Fisher, A. G., et al., 1971. Initial Reports of the Deep Sea Drilling Project, Volume VIII. Washington (U. S. Government Printing Office). in press.

1971. Bitumens and organic carbon in samples from DSDP Leg XI cores, in Hays, J. D., et al., 1971. Initial Reports of the Deep Sea Drilling Project, IX. Washington (U. S. Government Printing Office). in press.

Mommessin, P. R., Hood, A., Ellinton, W. E. and Manual, A. F., 1969. Analysis of organic matter in Core 5, Leg 1, Site 2, in Davis, J. B., and Bray, E. E. (1969), Above, Section $2.7,468$.

Phillippi, G. T., 1956. Identification of oil source beds by chemical means. Intern. Geol. Congr., 20th, Mexico, 1956, Rept. 25.

, 1965. On the depth, time and mechanism of petroleum generation. Geochim. Cosmochim. Acta. 29, 1021.

, 1968. Essentials of the petroleum formation process are organic source material and a subsurface temperature controlled chemical reaction mechanism, in Advances in Organic Chemistry. Ed. P. A. Schenk and I. Havanaar, Pergamon, Oxford, 25.

Rogers, M. A. and Koons, C. B., 1969. Organic carbon $\delta C^{13}$ values from Quaternary marine sequences in the Gulf of Mexico, a reflection of paleotemperature changes. Transactions-Gulf Coast Assoc. of Geol. Soc. $19,529$.

Ryan, W. E. F., et al. (1970). Deep sea drilling project, Leg 13, Geotimes. 15 , No. 10, 12.

Silverman, S. R. and Epstein, S., 1958. Carbon isotopic compositions of petroleum and other sedimentary organic materials. Bull. Am. Assoc. Petrol. Geologists.42, 998.

Staplin, F. L., 1969. Sedimentary organic matter, organic metamorphism and oil and gas occurrence. Bull. Canadian Petr. Geol. 17, 47. 4 